\title{
Predominant Lactic Acid Bacteria Involved in the Traditional Fermentation of Fufu and Ogi, Two Nigerian Fermented Food Products
}

\author{
Olaoluwa Oyedeji ${ }^{*}$, Samuel Temitope Ogunbanwo ${ }^{2}$, Anthony Abiodun Onilude ${ }^{2}$ \\ ${ }^{1}$ Department of Microbiology, Obafemi Awolowo University, Ile-Ife, Nigeria; ${ }^{2}$ Department of Microbiology, University of Ibadan, \\ Ibadan, Nigeria. \\ Email: *laoluoyedeji@gmail.com
}

Received August 28 $8^{\text {th }}, 2013$; revised September $28^{\text {th }}, 2013$; accepted October $5^{\text {th }}, 2013$

Copyright (C) 2013 Olaoluwa Oyedeji et al. This is an open access article distributed under the Creative Commons Attribution License, which permits unrestricted use, distribution, and reproduction in any medium, provided the original work is properly cited.

\begin{abstract}
Traditional methods of preparation were simulated in the laboratory fermentations of cassava and maize to produce fufu and ogi respectively. Changes in $\mathrm{pH}$, temperature and titratable acidity, as well as the diversity of lactic acid bacteria species were investigated during both fermentations. Lactic acid bacteria strains involved in the fermentation processes were isolated at twelve hourly intervals, characterized and identified using phenotypic and biochemical methods. A rapid decrease in $\mathrm{pH}, 5.6$ to 3.7 in fufu and 5.9 to 3.8 in ogi, were observed with temperature increasing from $26^{\circ} \mathrm{C}$ to $30^{\circ} \mathrm{C}$ and $25^{\circ} \mathrm{C}$ to $31^{\circ} \mathrm{C}$ in fufu and ogi respectively. Most of the lactic acid bacteria strains isolated were homofermentative and heterofermentative Lactobacillus species and heterofermentative Leuconostoc species. Lactobacillus plantarum and Leuconostoc mesenteroides were the dominant lactic acid bacteria species in fufu while L. cellobiosus, L. plantarum and Lc. lactis were dominant in ogi fermentation. An ecological succession pattern in which Leuconostoc species were mostly isolated during early stages of fermentation with the final stages populated with Lactobacillus species was observed in both cases and is attributable to differential acid tolerance of the two genera. The frequencies of dominance of the strains in fufu were L. plantarum $(56.25 \%)$, Lc. mesenteroides $(18.75 \%)$, L. lactis $(6.25 \%)$, L. coprophillus $(6.25 \%)$, L. acidophilus (6.25\%) and L. brevis (6.25\%). The frequencies of dominance in ogi were L. cellobiosus (26.6\%), Lc. lactis (26.6\%), L. plantarum (20.0\%), L. acidophilus (13.33\%) and Lc. paramesenteroides (13.33\%). The dominant strains can serve as potential starter cultures for fufu and ogi production.
\end{abstract}

Keywords: Lactic Acid Bacteria; Fermentation; Fufu; Ogi; Cassava; Maize; Fermented Foods

\section{Introduction}

Fermented foods are consumed throughout the world and traditional fermentation processes such as those involved in the production of fermented dairy products and alcoholic beverages have been performed for thousands of years [1]. These food products result from the activities of microorganisms which modify the flavour and texture and increase long term product stability [2]. Lactic acid bacteria constitute an important group of these organisms and have been associated with production of fermented foods and feeds for many centuries [3]. They are important in the production of many fermented foods such as sauerkraut, silage, sourdough, dry fermented sausages and cheeses [4]. Some of the reasons for their widespread

"Corresponding author. use are the ability to retard spoilage, preserve food as well as improve flavour and texture of foods. They also play fundamental role in microbial ecology of foods by synthesizing a variety of antimicrobial compounds such as organic acids, hydrogen peroxide, diacetyl and bacteriocins $[5,6]$. They are thus able to inhibit many microorganisms including spoilage and pathogenic organisms. They are increasingly being recognised for their health and nutritional benefits hence some strains are used as probiotics [7-10].

Among the many African, traditionally fermented foodstuffs are fufu and ogi. Fufu, a product of an acidfermented cassava root tuber serves as main course meals in most areas of Nigeria and Africa as a whole [11]. It is prepared by natural fermentation which transforms the cassava root from rapid spoilage after harvest as cassava 
roots are more perishable than other tuber crops such as yam and sweet potato. Cassava (Manihot esculenta) is a perennial woody shrub with an edible root which grows in tropical and sub-tropical areas of the world [12]. In Africa and Latin America, it is mostly used for human consumption, while in Asia and parts of Latin America, it is also used commercially for the production of animal feeds and starch-based products [13]. Other products obtained from fermented cassava roots are gari and lafun. $O g i$, an acid-fermented cereal gruel, is a major staple sour porridge food widely taken in West Africa. It also serves as the traditional infant weaning food [11]. It is generally obtained by fermenting maize grains (Zea mays).

In general, a wide spectrum of microorganisms is involved during fermentation processes but a few types usually determine the quality of the end product [14]. Given adequate environmental conditions, a particular microbial community will determine the quality of a specific food. The origin, development and succession of a particular microbial community in any food are thus governed by its ecological factors, which influence the physiological expression of microbial cells [15]. Thus strategies for food processing and preservation can be developed on the basis of ecological factors associated with specific foods and beverages [16].

Yeasts and wide varieties of bacteria strains were found to be associated with the fermentation of cassava roots and cereal grains where they contribute significantly to starch breakdown, acidification, detoxification and flavour enhancement [17]. Yeasts and lactic acid bacteria are therefore the most common microorganisms in a wide variety of traditional food and beverage fermentations [18]. Lactic acid bacteria are found in various stages of fermentation processes where they are useful in flavour and aroma development. They also inhibit spoilage bacteria and pathogens and confer several intestinal health and other health benefits related to blood cholesterol levels, immune competence and antibiotics [19]. The quality of the final product is a factor of the diversity and composition of microorganisms and their dynamics and frequency of occurrence. The objective of this research was therefore to isolate and characterize predominant lactic acid bacteria species during the course of traditional fufu and ogi fermentations.

\section{Materials and Methods}

\subsection{Collection of Raw Materials}

Unbroken maize grains (Zea mays) and freshly harvested cassava root tubers (Manihot esculenta) were obtained from the Bodija market in Ibadan, Oyo State, Nigeria. They were brought in sterile polythene bags to the laboratory for immediate processing.

\subsection{Laboratory Preparation of Fufu and Ogi}

The laboratory fermentation of cassava tubers and maize grains to produce fufu and ogi respectively, were carried out by simulating the traditional methods of processing (Figures 1 and 2).

\subsection{Physicochemical Analysis}

The hydrogen ion concentration $(\mathrm{pH})$ and temperature changes of the fermenting cassava mash and maize grains were measured at twenty four hourly intervals for $72 \mathrm{~h}$ using a Pye-Unicam $\mathrm{pH}$ meter and Mercury thermometer respectively [20]. The total titratable acid was determined as percentage lactic acid by titrating $25 \mathrm{ml}$ of the samples used for $\mathrm{pH}$ determinations against $0.1 \mathrm{~N}$ $\mathrm{NaOH}$. The volumes of the $0.1 \mathrm{~N} \mathrm{NaOH}$ used were noted. Duplicate determinations were made for each analysis [21].

\subsection{Microbiological Isolation}

Twenty five millilitre portions were aseptically removed at different stages of fermentation processes: raw water used for steeping cassava roots and maize grains; steep

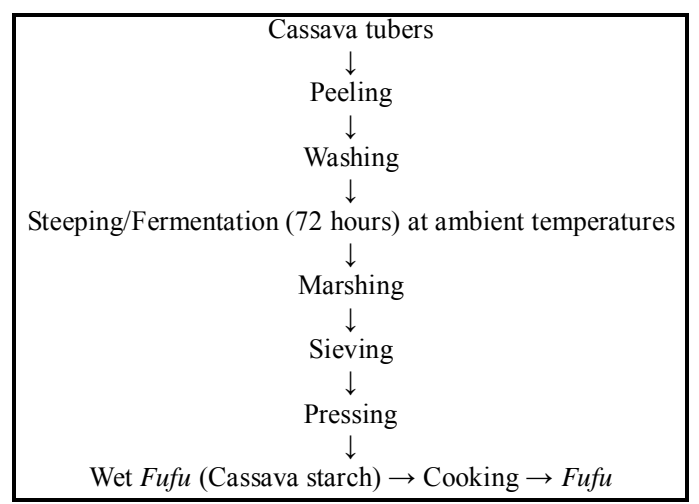

Figure 1. Traditional method of fufu processing.

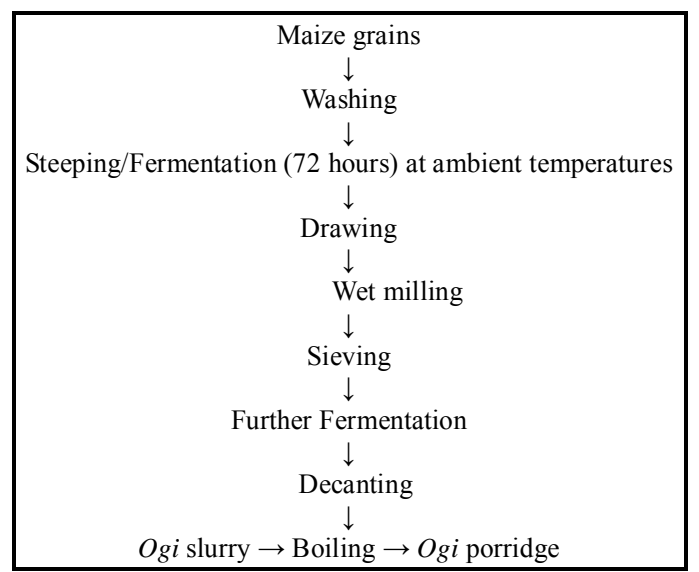

Figure 2. Traditional method of ogi processing. 
waters (sampled each day for $72 \mathrm{~h}$ ); water used for mashing steeped cassava and for milling ogi; the steep water used further fermentation of ogi and the final products of fermentation. Each sample was homogenized with 200 $\mathrm{ml}$ sterile $0.1 \%$ peptone water (Oxoid, UK). This was then serially diluted and $0.1 \mathrm{ml}$ from appropriate dilutions were spread plated on MRS agar plates (Oxoid, UK) in duplicates and incubated in Gas Pak jars (GasPak System, BBL) at $30^{\circ} \mathrm{C}$ for $72 \mathrm{~h}$. Colonies with distinct morphological differences such as colour, size and shapes were randomly picked from MRS agar plates as presumptive lactic acid bacteria isolates and repeatedly streaked on fresh MRS agar plates to purify the isolates. They were then maintained on appropriate slants at $4^{\circ} \mathrm{C}$.

\subsection{Characterisation and Identification}

Each of the lactic acid bacteria isolate was initially examined for colonial and cell morphologies, cell arrangement, spore formation and motility. Only the Gram positive, catalase negative and non spore forming isolates were then characterized by phenotypic and biochemical tests. An overnight culture (inoculums) of each isolate in MRS broth was used for all tests incubated anaerobically (GasPak System, BBL) at $30^{\circ} \mathrm{C}$. The lactic acid bacteria isolates were tested for fermentation of the following carbohydrates (Sigma, Germany): D-Glucose, lactose, sucrose, galactose, maltose, mannitol, sorbitol, mannose, L-arabinose, D-xylose, cellobiose, dulcitol, inositol, raffinose, rhamnose, inulin and salicin. Bromocresol purple broth base was used as basal medium. One percent filtersterilized sugar solution using $0.2 \mu \mathrm{m}$ Millipore filter (Corning) was added aseptically into sterilized bromocresol purple broth base before inoculation with $18-24 \mathrm{~h}$ old culture of each lactic acid bacteria strain. The results were assessed with reference to an uninoculated control after anaerobic incubation at $30^{\circ} \mathrm{C}$ for $5 \mathrm{~d}$. Tubes in which bromocresol purple colour changed to yellow indicated utilisation of sugar or acid production. The various lactic acid bacteria strains were then identified by reference to the Bergey's Manual of Systematic Bacteriology [22] and The Genera of Lactic Acid Bacteria [23] based on the results of the various tests. The identity of the lactic acid bacteria isolates were further confirmed by using the API $50 \mathrm{CHL}$ tests and the Computer Program APILAB Plus (BioMerieux, France).

\section{Results and Discussion}

The $\mathrm{pH}$ of the fermenting cassava roots decreased from 5.6 to 3.7 during the $72 \mathrm{~h}$ fermenting period. Correspondingly, the temperature increased from $26^{\circ} \mathrm{C}$ to $30^{\circ} \mathrm{C}$. The total titratable acidity (in \% lactic acid) increased from $0.07 \pm 0.01$ to $0.21 \pm 0.01$ and decreased to 0.09 by the end of $72 \mathrm{~h}$ fermentation period (Table 1). The $\mathrm{pH}$ of fermenting maize grains dropped from 5.9 to 3.8 by the end of the $72 \mathrm{~h}$ fermentation period. Correspondingly, the temperature increased from $25^{\circ} \mathrm{C}$ to $31^{\circ} \mathrm{C}$ during the same period while the total titratable acidity increased from $0.13 \pm 0.01$ to $0.28 \pm 0.01$ after 24 hours and then decreased to 0.14 by the end of fermentation period (Table 1).

During both fufu and ogi fermentation processes, the temperature of the fermenting materials increased as fermentation progressed. The two processes are thus exothermic in nature and the heat generated might have resulted from the metabolic activities of the fermenting organisms [24]. The fermenting organisms do contribute to acidity attributable to the production of lactic acid and acetic acid during the processes which exerts a depressive effect on the $\mathrm{pH}$ of the fermenting materials $[23,25]$.

Despite the unhygienic wet-milling and wet-sieving processes involved in the traditional preparation of both fufu and ogi, the low $\mathrm{pH}$ of the fermented products would make them safe for consumption. Also the acidic fermentation and lactic acid metabolites are responsible for inactivation of enterobacteriaceae including toxin-producing and foodborne infectious pathogens [26-29]. These result in an improvement of the aroma, flavor, texture, safety and shelf life of the food.

A total of 32 lactic acid bacteria strains were isolated from the various phases of the fermentation of cassava for fufu production while 14 strains were obtained from fermenting maize steep for ogi production. The isolates were subjected to various morphological, physiological and biochemical characterizations. The characteristics exhibited by the isolates were compared with those of standard strains for their identification [22,30]. All the isolates were Gram positive and catalase negative rods or cocci. All produced no endospore and were non motile. They were facultative anaerobes and were fermentative rather than being oxidative in nature (Table 2).

Table 3 shows the periodic distribution of dominant lactic acid bacteria strains during fermentation processes of fufu and ogi. Strains isolated from fufu fermentation included Lactobacillus plantarum, L. lactis, L. coprophillus, L. acidophilus, L. brevis and Leuconostoc mesenteroides while L. plantarum, L. cellobiosus, L. acidophilus, Lc. lactis and Lc. paramesenteroides were isolated from ogi fermentation. Ecological succession patterns in which the Leuconostoc species occur mostly at initial stages and the Lactobacillus species at later stages were observed in both fermentations. The most frequently isolated LAB species in fufu fermentation were $L$. plantarum (18 strains, $56.25 \%$ ) and Lc. mesenteroides (6 strains, $18.75 \%$ ) while in ogi, both L. cellobiosus and Lc. lactis had the highest percentage occurrence of $26.67 \%$ 

Food Products

Table 1. pH, temperature and titratable acid changes during the fermentation of cassava and maize for fufu and ogi production.

\begin{tabular}{ccccccc}
\hline \multicolumn{5}{c}{ Cassava (Fufu) } & \multicolumn{2}{c}{ Maize (Ogi) } \\
\hline Time (h) & Temperature $\left({ }^{\circ} \mathrm{C}\right)$ & $\mathrm{pH}$ & Titratable acidity $(\%$ lactic acid) & Temperature $\left({ }^{\circ} \mathrm{C}\right)$ & $\mathrm{pH}$ & Titratable acidity $(\%$ lactic acid) \\
\hline 0 & 26 & 5.6 & $0.07 \pm 0.01$ & 25 & 5.9 & $0.13 \pm 0.01$ \\
24 & 28 & 5.0 & $0.21 \pm 0.01$ & 27 & 5.2 & $0.28 \pm 0.01$ \\
48 & 29 & 4.4 & $0.13 \pm 0.01$ & 29 & 4.5 & 0.21 \\
72 & 30 & 3.7 & 0.09 & 31 & 3.8 & 0.14 \\
\hline
\end{tabular}

Table 2. Morphological and biochemical characterisation of isolates.

\begin{tabular}{|c|c|c|c|c|c|c|c|c|c|c|c|}
\hline Sample source & & & & $u f u$ & & & & & Ogi & & \\
\hline No. of strains & 18 & 2 & 2 & 2 & 2 & 6 & 2 & 4 & 2 & 4 & 2 \\
\hline $\begin{array}{l}\text { Gram reaction/ } \\
\text { Morphology }\end{array}$ & GPR & GPR & GPR & GPR & GPR & GPC & GPR & GPR & GPR & GPC & GPC \\
\hline Catalase & - & - & - & - & - & - & - & - & - & - & - \\
\hline Motility & - & - & - & - & - & - & - & - & - & - & - \\
\hline Methyl red & + & + & + & + & + & + & + & + & + & + & + \\
\hline Voges Proskauer & - & - & - & - & - & - & - & - & - & - & - \\
\hline Spore stain & - & - & - & - & - & - & - & - & - & - & - \\
\hline $\begin{array}{l}\text { Oxidative/ } \\
\text { Fermentative }\end{array}$ & $\mathrm{F}$ & $\mathrm{F}$ & $\mathrm{F}$ & $\mathrm{F}$ & $\mathrm{F}$ & $\mathrm{F}$ & $\mathrm{F}$ & F & $\mathrm{F}$ & $\mathrm{F}$ & $\mathrm{F}$ \\
\hline $\begin{array}{l}\text { Dextran } \\
\text { from sucrose }\end{array}$ & - & - & + & - & - & + & - & - & - & - & - \\
\hline $\begin{array}{l}\text { Fermentation } \\
\text { pattern }\end{array}$ & HMF & HMF & HTF & HTF & HMF & HTF & HMF & HTF & HMF & HMF & HTF \\
\hline $\mathrm{O}_{2}$ relationship & FA & FA & FA & FA & FA & FA & FA & FA & FA & FA & FA \\
\hline $\begin{array}{c}\text { Growth } \\
\text { in } 4 \% \mathrm{NaCl}\end{array}$ & + & - & - & - & + & - & + & + & - & + & - \\
\hline $\begin{array}{l}\text { Ammonia } \\
\text { from arginine }\end{array}$ & - & + & + & - & - & - & - & - & - & - & - \\
\hline Fermentation: & & & & & & & & & & & \\
\hline Glucose & + & + & + & + & + & + & + & + & + & + & + \\
\hline Lactose & + & + & + & + & + & + & + & + & + & + & - \\
\hline Sucrose & - & + & + & + & + & - & + & - & + & + & - \\
\hline Galactose & + & + & + & + & + & - & + & + & + & + & + \\
\hline Maltose & + & + & + & + & + & - & + & + & + & + & + \\
\hline Mannitol & + & - & - & + & + & - & + & + & + & + & + \\
\hline Sorbitol & + & - & - & + & + & - & + & + & + & + & + \\
\hline Mannose & + & - & - & + & + & - & + & + & + & + & - \\
\hline Arabinose & - & + & + & + & + & - & + & - & + & + & + \\
\hline Xylose & - & - & - & - & + & - & - & + & - & - & - \\
\hline Cellobiose & + & - & - & + & - & - & + & - & + & + & - \\
\hline Dulcitol & + & - & - & - & - & - & + & - & - & - & - \\
\hline Inositol & + & - & - & - & - & - & - & + & - & - & - \\
\hline Inulin & + & - & - & + & - & - & + & + & + & + & - \\
\hline Raffinose & + & + & + & - & - & + & + & - & - & + & + \\
\hline Rhamnose & + & - & - & + & + & - & - & + & + & - & - \\
\hline Salicin & + & + & + & + & - & - & + & - & + & + & - \\
\hline Identification & $\begin{array}{c}L . \\
\text { plantarum }\end{array}$ & $\begin{array}{c}L . \\
\text { lactis }\end{array}$ & $\begin{array}{c}\text { L. } \\
\text { coprophilu }\end{array}$ & $\begin{array}{l}\text { L. } \\
\text { acidophilus }\end{array}$ & L. brevis & $\begin{array}{c}L c . \\
\text { mesenteroides }\end{array}$ & $\begin{array}{c}L . \\
\text { plantarum }\end{array}$ & $\begin{array}{l}L . \\
\text { cellobiosus }\end{array}$ & $\begin{array}{l}\text { L. } \\
\text { acidophilus }\end{array}$ & $\begin{array}{l}\text { Lc. } \\
\text { lactis }\end{array}$ & $\begin{array}{c}L c . \\
\text { paramesenteroides }\end{array}$ \\
\hline
\end{tabular}


Table 3. Periodic distribution of dominant LAB strains during the fermentation of cassava and maize for fufu and ogi production.

\begin{tabular}{|c|c|c|}
\hline Period (h) & Fermentation & Dominating strains of LAB \\
\hline \multirow{2}{*}{0} & Fufu & L. plantarum, L. brevis, L. coprophillus, Lc. mesenteroides \\
\hline & Ogi & L. plantarum, L. cellobiosus, Lc lactis, Lc. paramesenteroides \\
\hline 24 & Ogi & L. plantarum, Lc. lactis, Lc. paramesenteroides, L. acidophilus, L. cellobiosus, \\
\hline 48 & Fufu & L. plantarum, L. acidophilus, L. lactis, L. brevis, Lc. mesenteroides \\
\hline \multirow{2}{*}{72} & Fufu & L. plantarum, L. acidophilus, L. brevis \\
\hline & Ogi & L. plantarum, L. cellobiosus, \\
\hline
\end{tabular}

followed by L. plantarum with occurrence of $20.0 \%$ (Figures 3 and 4). The frequencies of dominance of the lactic acid bacteria strains in fufu fermentation were $L$. plantarum $56.25 \%$, Lc. mesenteroides $18.75 \%$, L. lactis $6.25 \%$, L. coprophillus $6.25 \%$, L. acidophilus $6.25 \%$ and L. brevis $6.25 \%$. In ogi fermentation, they were L. cellobiosus $26.67 \%$, Lc. lactis $26.67 \%$, L. plantarum $20.0 \%$, Lc. paramesenteroides $13.33 \%$ and L. acidophilus $13.33 \%$.

Lc. mesenteroides and L. plantarum have been reported as the dominant microorganisms implicated in several natural and spontaneous lactic acid fermentation of vegetables [31,32]. L. plantarum was also found to dominate the lactic acid bacteria flora in various food fermentation processes for akamu [33], ogi [34], boza [35], cachaca [36], tempoyak [37], ting [38] and togwa [39].

Spontaneous fermentation typically results from the competitive activities of different microorganisms whereby strains best adapted and with the highest growth rate will dominate particular stages of the process [38]. Among the bacteria associated with food fermentation, lactic acid bacteria are of predominant importance. Samples from plant materials were reported to show the greatest diversity of lactic acid bacteria with the Lactobacillus strains being predominant in food-related ecosystems [40].

Yeasts and lactic acid bacteria are implicated in the fermentation of a wide variety of traditional food and beverage fermentations $[14,18,33,39]$. While yeasts are known to facilitate alcoholic fermentations, lactic acid bacteria produce lactic acid as part or major by product from the fermentation of carbohydrates [25,41]. Fufu and ogi are products of acid fermentations by lactic acid bacteria. This group of bacteria includes several genera that differ considerably in morphological, physiological and functional properties. Lc. mesenteroides mostly occur at early stages of most vegetable fermentations with $L$. plantarum predominating towards the end of the processes [14]. This ecological succession is attributed to the differences in the acid tolerance of the two genera. It may also be the reason for the disappearance of the entero-

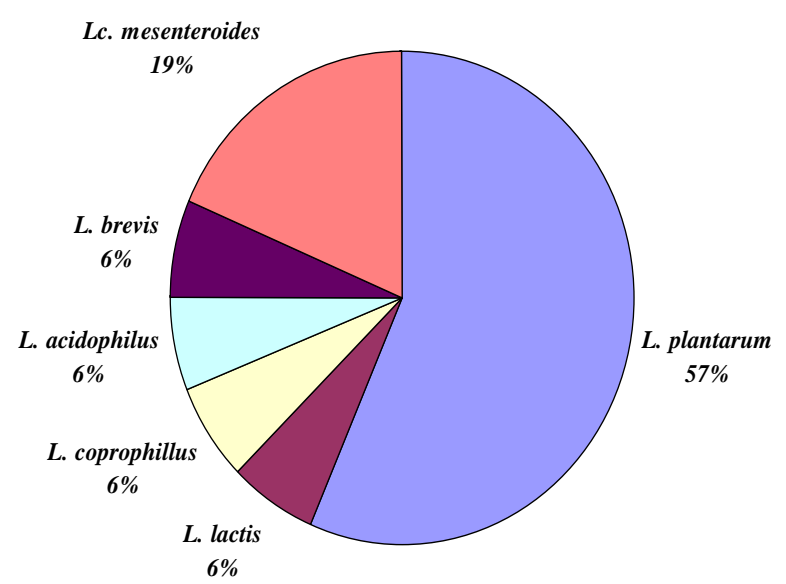

Figure 3. Percentage occurrence of lactic acid bacteria in fufu fermentation.

Lc.

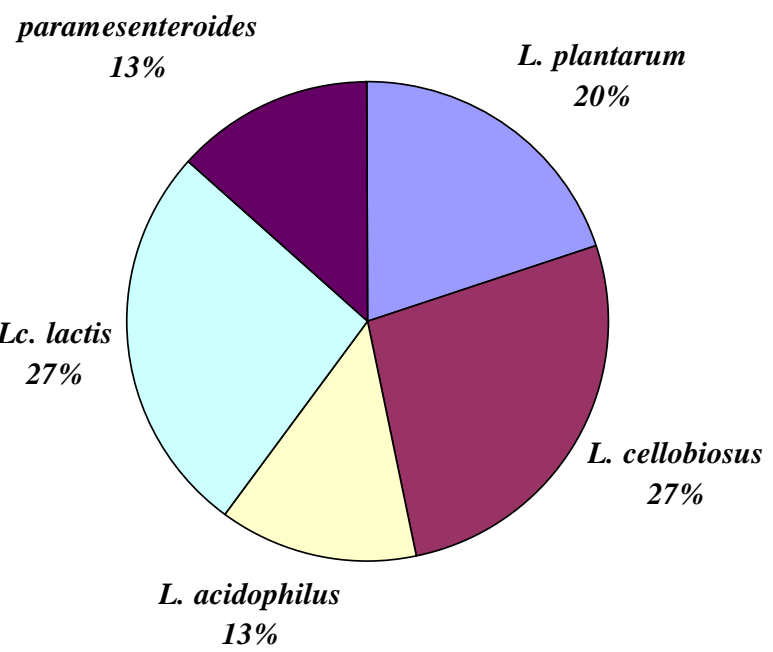

Figure 4. Percentage occurrence of lactic acid bacteria in ogi fermentation.

bacteriaceae which are observed at early periods during fermentation of plant materials [14]. The water used for steeping or surface microflora of raw materials may be sources of such enterobacteriaceae. 
The methods of preparation, water used for steeping, surface microflora of raw materials, atmosphere where processing takes place and the handlers all affect the types of microorganisms isolated during fermentation processes for fufu and ogi. The various species of lactic acid bacteria are however better adapted to the substrates and overcome the possible physiological and biochemical hurdles during the phases of each fermentation process. Fufu and ogi, as at present, are traditionally prepared by spontaneous fermentation relying on the indigenous flora of the raw materials. This leads to a poorly controlled process and variations in the products. For consistency in the quality of these fermented food products, the development of specific starter cultures is important.

\section{Conclusion}

It is concluded that an association of lactic acid bacteria composed of homofermentative and heterofermentative Lactobacillus species and heterofermentative Leuconostoc species are involved from the beginning to the end of both cassava and maize fermentations for the production of fufu and ogi respectively. Factors which influence these food fermentations include temperature, acidity and hydrogen ion concentration $(\mathrm{pH})$. The assessment of the performance of each of the species under controlled fermentation will enable selection of the best strains that can serve as potential starter culture for the production of microbiologically stable and predictable end products.

\section{REFERENCES}

[1] K. O. H. Steinkraus, "Indigenous Fermented Foods Involving Acid Fermentation/ Acid Fermented Cereal Gruel," In: Handbook of Indigenous Fermented Foods, Marcel Dekker Inc., 1983, pp. 189-218.

[2] W. Holzapfel, "Use of Starter Culture in Fermentation on a Household Scale," Food Control, Vol. 8, No. 5-6, 1997 , pp. 241-258.

http://dx.doi.org/10.1016/S0956-7135(97)00017-0

[3] A. I. Sanni, A. A. Onilude, S. T. Ogunbanwo and S. I. Smith, "Antagonistic Activity of Bacteriocin Produced by Lactobacillus species from Ogi, an Indigenous Fermented Food," Journal of Basic Microbiology, Vol. 39, No. 3, 1999, pp. 189-195.

http://dx.doi.org/10.1002/(SICI)1521-4028(199906)39:3< 189::AID-JOBM189>3.0.CO;2-R

[4] A. H. Rose, "Economic Microbiology, Microbiology of Fermented Foods," Academic Press, London, 1982.

[5] T. R. Klaenhammer, "Bacteriocins of Lactic Acid Bacteria," Biochemie, Vol. 70, No. 3, 1988, pp. 337-349. http://dx.doi.org/10.1016/0300-9084(88)90206-4

[6] M. V. Leal, M. Baras, J. L. Ruiz-Barba, B. Floriano and R. Jimenez-Diaz, "Bacteriocin Production and Competitiveness of Lactobacillus plantarum LPCO10 in Olive Juice Broth, a Culture Medium Obtained from Olives,"
International Journal of Food Microbiology, Vol. 43, No. 1-2, 1998, pp. 129-134. http://dx.doi.org/10.1016/S0168-1605(98)00079-8

[7] S. E. Gilliland, "Health and Nutritional Benefits of Lactic Acid Bacteria," FEMS Microbiology Reviews, Vol. 87, No. 1-2, 1990, pp. 175-188.

[8] S. Salminen, M. Deighton and S. Gorbach, "Lactic Acid Bacteria in Health and Disease," In: S. Salminen and A. Van Wright, Eds., Lactic Acid Bacteria, Marcel Dekker Inc., New York, 1993, pp. 234-294.

[9] C. M. Chapman, G. R. Gibson and I. Rowland, "Health Benefits of Probiotics: Are Mixtures More Effective than Single Strains?" European Journal of Nutrition, Vol. 50, No. 1, 2011, pp. 1-17. http://dx.doi.org/10.1007/S00394-010-0166-Z

[10] M. V. Herias, C. Hessle, E. Telemo, T. Midtvedt, L. A Hanson and A. E. Wold, "Immunomodulatory Effects of Lactobacillus plantarum Colonizing the Intestine of Gnotobiotic Rats," Clinical and Experimental Immunology, Vol. 116, No. 2, 1999, pp. 283-290. http://dx.doi.org/10.1046/j.1365-2249.1999.00891.x

[11] S. A. Odunfa, "African Fermented Foods," In: B. J. B. Wood, Ed., Microbiology of Fermented Foods, Vol. 2, Elsevier Applied Science Publishers, London, 1985, pp. 155-191.

[12] M. M. Burrell, "Starch: The Need for Improved Quality or Quantity and Overview," Journal of Experimental Botany, Vol. 218, No. 382, 2003, pp. 451-456.

[13] FAO, "Production Yearbook," Vol. 44, 1990, FAO, Rome.

[14] K. Abegaz, "Isolation, Characterization and Identification of Lactic Acid Bacteria Involved in Traditional Fermentation of Borde, an Ethiopian Cereal Beverage," African Journal of Biotechnology, Vol. 6, No. 12, 2007, pp. 14691478.

[15] T. Deak and L. R. Beuchat, "Handbook of Spoilage Yeasts," CRC Press Inc., Boca Raton, 1996, pp. 1-36,61154.

[16] G. W. Gould, "Ecosystem Approaches to Food Preservation," Journal of Applied Bacteriology, Vol. 73, No. S21, 1992, pp. 58S-68S.

[17] O. B. Oyewole, "Fermentation of Cassava for Lafun Production," Food Laboratory News, Vol. 17, No. 2, 1991, pp. 29-31.

[18] S. K. Soni, D. K. Sandhu, K. S. Vikhu and N. Kamra, "Microbiological Studies on Dosa Fermentation," Food Microbiology, Vol. 3, No. 1, 1986, pp. 45-53. http://dx.doi.org/10.1016/S0740-0020(86)80025-9

[19] W. E. Sandine, "Looking Backward and Forward at the Practical Applications of Genetic Research on Lactic Acid Bacteria," FEMS Microbiology Reviews, Vol. 46, No. 3, 1987, pp. 205-220.

[20] AOAC, "Official Methods of Analytical Chemists," AOAC, Arlington, 1984

[21] D. Pearson, "Laboratory Techniques in Food Analysis," Butterworth, London, Boston, 1973, pp. 50-57.

[22] P. H. A. Sneath, N. S. Mair, M. E. Sharpe and J. G. Holt, 
"Bergey's Manual of Systematic Bacteriology," Williams Wilkins, Baltimore, 1986.

[23] B. J. B. Wood and W. H. Holzapfel, "The Genera of Lactic Acid Bacteria," Blackie Academic and Professional, Chapman and Hall, Glasgow, 1995.

[24] P. K. Sarkar and J. P. Tamang, "The Influence of Process Variation and Inoculum Composition on the Sensory Qualities of Kinema," Food Microbiology, Vol. 11, No. 4, 1994, pp. 317-325. http://dx.doi.org/10.1006/fmic.1994.1036

[25] K. H. Steinkraus, "Fermentations in World Food Processing," Comprehensive Reviews in Food Science and Food Technology, Vol. 1, No. 1, 2002, pp. 23-32.

[26] W. S. M. Lorri, "Nutritional and Microbiological Evaluation of Fermented Cereal Weaning Foods," Ph.D. Thesis, Department of Food Sciences, Chammers University of Technology, Gotenborg, 1993.

[27] Y. B. Byaruhanga, B. H. Bester and T. G. Watson, "Growth and Survival of Bacillus cereus in Mageu, a Sour Maize Beverage," World Journal of Microbiology and Biotechnology, Vol. 15, No. 3, 1999, pp. 329-333. http://dx.doi.org/10.1023/A:1008967117381

[28] N. F. Kunene, J. W. Hastings and A. Von Holy, "Bacterial Populations Associated with a Sorghum-Based Weaning Cereal," International Journal of Food Microbiology, Vol. 49, No. 1-2, 1999, pp. 75-83. http://dx.doi.org/10.1016/S0168-1605(99)00062-8

[29] A. T. C. Ana, A. P. Rosinea, C. M. Hilario and A. M. Celia, "Inhibition of Listeria monocytogenes by Lactic Acid Bacteria Isolated from Italian Salami," Food Microbiology, Vol. 23, No. 3, 2006, pp. 213-219. http://dx.doi.org/10.1016/j.fm.2005.05.009

[30] M. E. Sharpe, "Identification Methods for Microbiologists," 2nd Edition, Acad. Press Soc., 1979, pp. 233-259.

[31] L. G. McDonald, H. P. Flemming and H. M. Hassan, "Acid Tolerance of Leuconostoc mesenteroides and Lactobacillus plantarum," Applied and Environmental Microbiology, Vol. 57, No. 7, 1990, pp. 2120-2124.

[32] E. Makimattila, M. Kahala and V. Joutsjoki, "Characterization and electrotransformation of Lactobacillus plantarum and Lactobacillus paraplantarum Isolated from Fermented Vegetables," World Journal of Microbiology and Biotechnology, Vol. 27, No. 2, 2011, pp. 371-379. http://dx.doi.org/10.1007/s11274-010-0468-6

[33] P. C. Obinna-Echem, V. Kuri and J. Beal, "Evaluation of the Microbial Community, Acidity and Proximate Com- position of Akamu, a Fermented Maize Food," Journal of the Science of Food and Agriculture, 2013. http://dx.doi.org/10.1002/.jsfa.6264

[34] M. L. Johansson, A. Sanni, C. Lonner and G. Molin, "Phenotypically Based Taxonomy using API 50CH of Lactobacilli from Nigerian Ogi, and the Occurrence of Starch Fermenting Strains," International Journal of Food Microbiology, Vol. 25, No. 2, 1995, pp. 159-168. http://dx.doi.org/10.1016/0168-1605(94)00096-O

[35] V. Getcheva, S. S. Pandiella, A. Angelov, Z. G. Roshkova and C. Webb, "Microflora Identification of the Bulgarian Cereal-based Fermented Beverage Boza," Process Biochemistry, Vol. 36, No. 1-2, 2000, pp. 127-130. http://dx.doi.org/10.1016/S0032-9592(00)00192-8

[36] F. C. O. Gomes, C. L. C. Silva, C. R. Vianna, I. C. A. Lacerda, B. M. Borreli, A. C. Nunes, G. R. Franco, M. M. Mourao and C. A. Rosa, "Identification of Lactic Acid Bacteria Associated with Traditional Cachaca Fermentations," Brazilian Journal of Microbiology, Vol. 41, No. 2, 2010, pp. 486-492.

http://dx.doi.org/10.1590/S1517-83822010000200031

[37] J. I. Leisner, M. Vancanneyt, G. Rusul, B. Pot, K. Lefebvre, A. Fresi and L. K. Tee, "Identification of Lactic Acid Bacteria Constituting Predominating Microflora in an Acid-Fermented Condiment (Tempoyak) Popular in Malaysia," International Journal of Food Microbiology, Vol. 63, No. 1-2, 2001, pp. 149-157. http://dx.doi.org/10.1016/S0168-1605(00)00476-1

[38] E. Madoroba, E. T. Steenkamp, J. Theron, G. Huys, I. Schierlinck and T. E. Cloete, "Polyphasic Taxonomic Characterization of Lactic Acid Bacteria Isolated from Spontaneous Sorghum Fermentations Used to Produce Ting, a Traditional South African Food," African Journal of Biotechnology, Vol. 8, No. 3, 2009, pp. 458-463.

[39] J. K. Mugula, S. A. M. Ninko, J. A. Narvhus and T. Sorhaug, "Microbiological and Fermentation Characteristics of Togwa, a Tanzanian Fermented Food," International Journal of Food Microbiology, Vol. 80, No. 3, 2003, pp. 187-199. http://dx.doi.org/10.1016/S0168-1605(02)00141-1

[40] L. H. Damelin, G. A. Dykes and A. Von Holy, "Biodiversity of Lactic Acid Bacteria from Food-Related Ecosystem," Microbios, Vol. 83, No. 334, 1995, pp. 13-22.

[41] C. F. Williams and C. W. Dennis, "Food Microbiology," 4th Edition, McGraw Hill, 2011, p. 330. 